\title{
Enhancement of synthesis of extracellular matrix proteins on retinoic acid loaded electrospun scaffolds
}

Citation for published version (APA):

Damanik, F. F. R., van Blitterswijk, C., Rotmans, J., \& Moroni, L. (2018). Enhancement of synthesis of extracellular matrix proteins on retinoic acid loaded electrospun scaffolds. Journal of Materials Chemistry. B, Materials for Biology and Medicine, 6(40), 6468-6480. https://doi.org/10.1039/c8tb01244j

Document status and date:

Published: 28/10/2018

DOI:

10.1039/c8tb01244j

Document Version:

Publisher's PDF, also known as Version of record

Document license:

Taverne

Please check the document version of this publication:

- A submitted manuscript is the version of the article upon submission and before peer-review. There can be important differences between the submitted version and the official published version of record.

People interested in the research are advised to contact the author for the final version of the publication, or visit the DOI to the publisher's website.

- The final author version and the galley proof are versions of the publication after peer review.

- The final published version features the final layout of the paper including the volume, issue and page numbers.

Link to publication

\footnotetext{
General rights rights.

- You may freely distribute the URL identifying the publication in the public portal. please follow below link for the End User Agreement:

www.umlib.nl/taverne-license

Take down policy

If you believe that this document breaches copyright please contact us at:

repository@maastrichtuniversity.nl

providing details and we will investigate your claim.
}

Copyright and moral rights for the publications made accessible in the public portal are retained by the authors and/or other copyright owners and it is a condition of accessing publications that users recognise and abide by the legal requirements associated with these

- Users may download and print one copy of any publication from the public portal for the purpose of private study or research.

- You may not further distribute the material or use it for any profit-making activity or commercial gain

If the publication is distributed under the terms of Article $25 \mathrm{fa}$ of the Dutch Copyright Act, indicated by the "Taverne" license above, 
Check for updates

Cite this: J. Mater. Chem. B, 2018, 6,6468

Received 10th May 2018,

Accepted 30th August 2018

DOI: $10.1039 / c 8 t b 01244 j$

rsc.li/materials-b

\section{Enhancement of synthesis of extracellular matrix proteins on retinoic acid loaded electrospun scaffolds $\dagger$}

\author{
Febriyani F. R. Damanik, ${ }^{\text {ab }}$ Clemens van Blitterswijk, $^{\text {ab }}$ Joris Rotmans $^{c}$ and \\ Lorenzo Moroni (iD *ab
}

\begin{abstract}
Electrospinning is a renowned technique for the generation of ultrafine, micro- and nanoscale fibres due to its simplicity, versatility and tunability. Owing to its adaptability to a wide selection of materials and scaffold architectures, electrospun meshes have been developed as biocompatible scaffolds and drug delivery systems for tissue engineering. Here, we developed a drug delivery scaffold by electrospinning poly( $\varepsilon$-caprolactone) (PCL) directly blended with a therapeutic agent, retinoic acid (RA), at different concentrations. The release profile, DNA, and elastin analysis of direct and transwell seeded RA-loaded PCL electrospun scaffolds showed desirable controlled release at $15 \mathrm{kV}$ fabrication, with $0.01 \% \mathrm{RA}$ as the optimum concentration. The selected $0.01 \%(\mathrm{w} / \mathrm{v})$ RA-loaded PCL meshes were further analysed using five different seeding cultures to investigate and extensively distinguish the effects of RA release with or without cell contact to the PCL electrospun meshes for cell morphology, proliferation and extracellular matrix (ECM) protein secretion of collagen and elastin. Upon exposure to RA-loaded PCL scaffolds, an increase of human dermal fibroblast (HDF) proliferation was observed. In contrast, human mesenchymal stromal cell (hMSC) cultures showed a decrease in cell proliferation. For both hMSC and HDF cultures, exposure to RA-loaded $\mathrm{PCL}$ scaffolds provided a significant increase in elastin production per cell. For collagen expression, a slight increase was measured and was outperformed by the 3D geometry stimulation from PCL scaffolds. In contrast to hMSCs, HDFs showed enhanced stress actin fibres in cultures with RA-loaded PCL scaffolds. Both cell types exhibited more vinculin expression when seeded to RA-loaded PCL scaffolds. Hence, electrospun scaffolds releasing RA in a controlled manner were able to regulate cell proliferation, morphology and ECM secretion, and present an attractive approach for optimizing tissue regeneration.
\end{abstract}

\section{Introduction}

Electrospinning is a versatile technique for the fabrication of micro- and nanoscale fibres. A high voltage source is used to apply an electric field to the polymer solution, which creates a jet, traveling to the grounded collector as an ultrafine fibre. The fibre size, architecture, and surface topography of the collected mesh can be directly tuned by various processing parameters, such as voltage, flow rate, temperature and humidity. ${ }^{1}$ The applied voltage is a crucial processing parameter for providing

\footnotetext{
${ }^{a}$ University of Twente, Drienerlolaan 5, Zuidhorst 145, 7522 NB Enschede, The Netherlands

${ }^{b}$ Maastricht University, MERLN Institute for Technology-Inspired Regenerative Medicine, Universiteitsingel 40, 6229 ER Maastricht, The Netherlands. E-mail:l.moroni@maastrichtuniversity.nl

${ }^{c}$ Department of Internal Medicine, Leiden University Medical Center, Albinusdreef 2, 2333ZA Leiden, The Netherlands

$\dagger$ Electronic supplementary information (ESI) available. See DOI: 10.1039/ c8tb01244j
}

a high electric field necessary to create a continuous polymeric jet for the desired fibre formation. ${ }^{2}$ In general, the fibre diameter can be tuned by increasing the applied voltage, resulting in smaller diameters of the fibres. ${ }^{3-5}$ Electrospinning is a preferred technique in comparison to other conventional fibre fabrication techniques, such as template synthesis, self-assembly or phase separation, due to its simple base equipment, relatively easy procedure and broad selection of materials. ${ }^{6}$

The ease of fabrication and single-step modification of drug incorporation makes electrospinning a technique widely used for various applications, including tissue regeneration, cosmetics, filtration, smart textiles, and electronics. ${ }^{7}$ In the field of tissue engineering, fabrication of porous 3D meshes via electrospinning has been used to mimic the extracellular matrix (ECM) as a scaffold for cell growth. ${ }^{8}$ In addition to the scaffold architecture, the used polymer type needs to be biocompatible and biodegradable to be safely replaced by the regenerated tissues. ${ }^{9}$ Though electrospun natural polymers provide a closer resemblance to the ECM, synthetic polymers 
are more often used due to their versatility and processability. ${ }^{10}$ Poly(E-caprolactone) (PCL), a biocompatible, bioresorbable low-cost polymer, is one of the many examples of synthetic polymers used in electrospinning for tissue regeneration. ${ }^{11}$ Furthermore, owing to their adaptability and high surface area, electrospun meshes have been considered an excellent vehicle for various drugs, such as chemical agents, antibiotics, proteins, and DNA. ${ }^{12}$ The simplest and most straightforward method of incorporating drugs via electrospinning is by directly blending the drug with the polymer solution to electrospin.

Many drugs have a limited half-life and may exhibit side effects if exposure is not localized or excessive. An advantage of embedding therapeutic drugs is to preserve their functional lifetime and localize exposure, and preferably release them in a controlled manner. ${ }^{13}$ Therapeutic agents, such as retinoic acid (RA), a metabolite of vitamin A, have been shown to regulate cellular behaviour during development and regeneration, and influence the expression of ECM proteins in a dose-dependent manner. ${ }^{14}$ Varani et al. ${ }^{15}$ induced cell proliferation and ECM protein secretion, including collagen, in a growth-inhibited human dermal fibroblast (HDF) culture after introduction of RA at a specific concentration, and inhibition of collagen secretion at higher concentrations. Furthermore, RA has been observed to upregulate elastin expression in a dose-dependent fashion in other fibroblastic cells. ${ }^{16,17}$ Restoring declined elastin synthesis has also been seen in vascular smooth muscle cell (VSMC) cultures after exposure to specific concentrations of RA. ${ }^{18}$

Tissue engineered blood vessels (TEBVs) could provide a suitable substitute for prosthetic grafts. Most vascular tissue engineering approaches aim to develop readily available vascular grafts consisting of isolated cells seeded onto the natural or synthetic extracellular matrix (ECM) prior to implantation into the vasculature. ${ }^{19-21}$ Previously, we defined an in vivo bioreactor approach that allowed a surface modified polymeric rod to generate an autologous TEBV in vivo in only a few weeks. $^{22}$ This strategy employs the foreign body response (FBR) upon subcutaneous implantation to form a fibrocellular tissue capsule around the modified polymeric rod. Extrusion and engraftment of this capsule into the vasculature allows differentiation to a vascular phenotype. In time, the flow and wall tension of the vasculature provides enhancement in ECM synthesis, vessel wall thickening and VSMC differentiation from the (myo)fibroblasts found in the tissue capsule, remodelling it to the optimum vascular graft. ${ }^{23}$ Nevertheless, due to the ample remodelling, enwrapping with a functionalized electrospun mesh is necessary to provide a necessary support and trigger initial ECM synthesis enhancement.

Hence, developing a controlled release of RA from a biocompatible electrospun mesh could be a promising approach to regenerate new tissues and regulate ECM remodelling of the TEBV. Here, we blend RA at different concentrations with PCL and examined its controlled release to regulate cell behaviour and ECM protein secretion. The cell proliferation, morphology and ECM protein production of collagen, elastin and glycosaminoglycans (GAGs) were examined using human dermal fibroblasts (HDFs) and mesenchymal stromal cells (hMSCs).
Elastin was examined using a rat and human in vitro model to compare it to previous in vitro mimicking FBR studies ${ }^{22}$ and hopefully provide a closer prediction of implantation into human patients.

\section{Materials and methods}

\section{Fabrication of PCL and loaded PCL electrospun scaffolds}

Poly( $\varepsilon$-caprolactone) (PCL) $\left(M_{\mathrm{w}}: 45000\right)$, anhydrous chloroform, DMSO, all trans-retinoic acid (RA, molar mass $=300.4 \mathrm{~g} \mathrm{~mol}^{-1}$ ), and minoxidil (Mn, molar mass $=209.2 \mathrm{~g} \mathrm{~mol}^{-1}$ ) were purchased from Sigma Aldrich. Fabrication of electrospun scaffolds was done using PCL dissolved in 8:2 anhydrous chloroform and methanol at a $30 \% \mathrm{w} / \mathrm{v}$ concentration and gently stirred overnight. For loaded PCL, the dissolved polymer solution was added to either RA or Mn dissolved in DMSO to achieve a concentration of $0.25,0.05$ and $0.01 \%(\mathrm{w} / \mathrm{v})$. Electrospinning was carried out at 15 and $30 \mathrm{kV}, 15 \mathrm{~cm}$ working distance, $30 \%$ humidity, $25{ }^{\circ} \mathrm{C}$ temperature and $1 \mathrm{ml} \mathrm{h}^{-1}$ flow rate. All reagents and materials were purchased from Sigma Aldrich.

\section{Loading and release of RA from loaded PCL electrospun scaffolds}

Loaded PCL electrospun scaffolds $(n=3)$ with a diameter of $13 \mathrm{~mm}$ were punched from a $20 \times 22 \mathrm{~cm}^{2}$ electrospun mat made from $1 \mathrm{ml}$ solution of 30\% w/v PCL and either $0.25,0.05$ or $0.01 \%(\mathrm{w} / \mathrm{v})$ RA. The total loaded RA per scaffold was calculated based on the amount of RA added to the $30 \%$ PCL solution, divided by the total area of the fabricated electrospun mat and multiplied by the surface area of the punched scaffolds. For release scaffolds were incubated at $37{ }^{\circ} \mathrm{C}$ in PBS $(1 \times$, Gibco), collected at days $1-7$, and refreshed every 24 hours. Absorbance measurements of samples and standards were taken at $350 \mathrm{~nm}$ for RA and $280 \mathrm{~nm}$ for $\mathrm{Mn}$.

\section{Scaffold characterisation}

The fabricated PCL and RA-loaded PCL electrospun scaffolds were gold sputtered (Cressington 108 auto) at $40 \mathrm{~mA}$ and $100 \mathrm{mTorr}$ for 30 seconds. The fibre morphology and size were observed using a scanning electron microscope (SEM) (XL 30 ESEM-FEG, Philips/FEI). Images of $1000 \times$ for $15 \mathrm{kV}$ and $5000 \times$ for $30 \mathrm{kV}$ electrospun scaffolds were captured and examined for homogeneity and fibre diameter measurements. The fibre diameter was determined using ImageJ (National Institutes of Health, Bethesda, MD, USA).

\section{Cell isolation and expansion}

Bone marrow-derived mesenchymal stromal cells (hMSCs) were isolated from bone marrow aspirates and expanded as previously described. ${ }^{24}$ hMSCs and human dermal fibroblasts (HDFs, \#R2320, ScienCell Research Laboratories) were cultured in a culture medium comprising $\alpha$-MEM (Gibco), foetal bovine serum (10\%, Lonza), ascorbic acid ( $0.2 \mathrm{mM}$, Gibco), $\mathrm{L}$-glutamine ( $2 \mathrm{mM}$, Gibco), penicillin (100 $\mathrm{U} \mathrm{ml}^{-1}$ ) and streptomycin (100 $\mathrm{mg} \mathrm{ml}^{-1}$, Gibco). hMSCs and HDFs were expanded at initial seeding densities of 
3000 cells per $\mathrm{cm}^{2}$ and 5000 cells per $\mathrm{cm}^{2}$, respectively, in the culture medium in a $5 \% \mathrm{CO}_{2}$ humid atmosphere at $37{ }^{\circ} \mathrm{C}$. For both cell types, cultures were refreshed every 2-3 days and harvested at $80-90 \%$ confluency, for cell seeding.

\section{In vitro study - cell seeding}

The electrospun scaffolds were sterilized using $70 \%$ ethanol (Sigma Aldrich) and washed with PBS. Electrospun scaffolds of $19 \mathrm{~mm}$ in diameter were used to examine HDF growth and elastin synthesis at different RA concentrations. Further analysis on the selected RA-loaded PCL electrospun scaffold effects on hMSC and HDF proliferation, and ECM protein secretion using $13 \mathrm{~mm}$ diameter electrospun scaffolds was done.

Cell seeding was performed with cells at passage 4. For direct seeding, cells were seeded directly to the PCL (cell-ESP, control) and RA-loaded PCL (cell-ESP(RA), RA at different concentrations) electrospun scaffolds. For transwell seeding, cells were seeded on cell cultured treated well plates (NUNC, Thermo-Scientific), in which transwells ( $8 \mu \mathrm{m}$ polycarbonate pore size, Corning) were placed on top with (cell-RA, RA at different concentrations) or without (cells, control) electrospun scaffolds. In cell-ESP-RA cultures, cells were directly seeded on PCL electrospun scaffolds, with an addition of RA-loaded PCL electrospun scaffolds separated by a transwell.

A cell seeding density of 50000 HDFs was used to preselect the RA concentration, while 25000 hMSCs and 10000 HDFs were seeded for further analysis of the selected RA-loaded PCL electrospun scaffolds. A confluent layer study was conducted by seeding 100000 HDFs to cell cultured treated well plates and upon confluency PCL and RA-loaded PCL electrospun scaffolds were layered to the confluent cell layer (direct seeding) or placed in a transwell (transwell seeding). The preselection culture was observed at days 1,2 and 4, the confluent layer at day 2, and the selected RA culture at days 2 and 5. All cell experiments were performed in a $5 \% \mathrm{CO}_{2}$ humid atmosphere at $37{ }^{\circ} \mathrm{C}$.

\section{Cell growth and GAG assay}

Samples $(n=3)$ of all time points were washed gently with PBS and stored at $-80{ }^{\circ} \mathrm{C}$ overnight. The electrospun samples were transferred to Eppendorf tubes. Cell amount quantification was done using CyQuant Cell Proliferation Assay Kit (Molecular Probes). In brief, the frozen samples were incubated in lysis buffer (1:20 lysis buffer $20 \times)$ and underwent three times freeze-thaw cycles and incubated for 1 hour. An additional 1 hour incubation with lysis buffer RNase was conducted and DNA assay was performed following the CyQuant DNA assay (Molecular Probes, Oregon, USA). CyQuant GR dye $(1 \times)$ was mixed at $1: 1$ ratio with the cell lysate in a black 96-well plate (NUNC, Thermo-Scientific) and the mixture was incubated for 15 minutes at room temperature (RT) in the dark. Fluorescence was measured using a spectrophotometer (VICTOR3 Multilabel Plate Reader, Perkin Elmer Corporation) at excitation and emission wavelengths of 480 and $520 \mathrm{~nm}$, respectively.

The remaining lysis buffer solution was used to quantify sulphated GAGs and proteoglycans spectrophotometrically with 9-dimethylmethylene blue chloride (DMMB) (Sigma Aldrich) dye in PBE buffer (14.2 $\mathrm{g} \mathrm{l}^{-1} \mathrm{Na}_{2} \mathrm{HPO}_{4}$ and $3.72 \mathrm{~g} \mathrm{l}^{-1} \mathrm{Na}_{2}$ EDTA, $\mathrm{pH}$ 6.5). Absorbance was measured at $520 \mathrm{~nm}$ using a microplate reader (Bio-TEK Instruments) and quantification was done with reference to chondroitin sulphate B (Sigma-Aldrich) as the standard. For simplicity, the contents of sulphated GAGs and proteoglycans will be referred to as GAG in the following results.

\section{Collagen and elastin assay}

Collagen samples $(n=3)$ at day 5 underwent collagen extraction using a cold acid pepsin solution $\left(0.1 \mathrm{mg} \mathrm{ml}^{-1}\right.$ in $0.5 \mathrm{M}$ acetic acid) and incubated at $4{ }^{\circ} \mathrm{C}$ overnight. Collagen was then isolated and concentrated according to the Sircol collagen dye binding assay kit (Biocolor Ltd) and measured at $540 \mathrm{~nm}$. An additional collagen sample $(n=1)$ was collected and stained directly with Sirius Red in picric acid (Dye Reagent, Biocolor Ltd). For preselection studies at day 4, and selected RA-loaded PCL studies at day 5, cells were collected from elastin samples $(n=3)$ using trypsin-EDTA $(0.25 \%)$, counted and heated at $100{ }^{\circ} \mathrm{C}$ in oxalic acid $(0.25 \mathrm{M})$ for 1 hour to extract soluble $\alpha$-elastin. Elastin staining was conducted using the Fastin elastin assay kit (Biocolor Ltd) and measured at $513 \mathrm{~nm}$. Measurements were normalized by the amount of counted cells.

\section{Cell morphology from scanning electron imaging and immunostaining}

All chemicals were supplied by Sigma Aldrich, if not stated otherwise. Seeded electrospun scaffolds $(n=4)$ were washed with PBS and fixed with 4\% paraformaldehyde for 30 minutes at RT. After rinsing with PBS, electrospun scaffolds $(n=2)$ underwent $70-80-90-100 \%$ dehydration steps of 30 minutes each, followed by 1:1 incubation with hexamethyldisilazane (HMDS) and ethanol for 30 minutes. Samples were then incubated with $100 \%$ HMDS and left to evaporate overnight. All samples were gold sputtered (Cressington 108 auto) for 30 seconds at $40 \mathrm{~mA}$ and 100 mTorr. The cell morphology was studied at $250 \times$ magnification using a Philips XL30 ESEM-FEG SEM at $10 \mathrm{kV}$ and a working distance of $10 \mathrm{~mm}$. The remaining fixated electrospun scaffolds $(n=2)$ were permeabilized and blocked with TBP buffer $(0.1 \%$ Triton $\mathrm{X}-100,0.5 \%$ bovine serum albumin in PBS) at $4{ }^{\circ} \mathrm{C}$ overnight. Cells were stained with Vinculin-FITC (1:400), Phalloidin-Texas Red (Molecular Probes, $1: 100)$ and DAPI $(1: 100)$ with three times washing steps in between. Images were taken using a fluorescence microscope (Nikon Eclipse E600) at magnification $40 \times$.

\section{Statistical analysis}

Statistical analysis was executed using Graphpad and data were expressed as mean \pm s.d. Statistical analysis was done using Two-way Analysis of Variance (ANOVA) with Bonferroni's multiple comparison test $(p<0.05)$, unless otherwise indicated in the figure legends. For all figures the following applies: ${ }^{*}=p<0.05,{ }^{* *}=p<0.01$, and ${ }^{* *}=p<0.001$. 


\section{Results}

\section{Characterization of PCL and RA-loaded PCL electrospun scaffolds}

RA-loaded PCL electrospun scaffolds processed at $15 \mathrm{kV}$ showed similar fibre morphology and diameter to PCL electrospun scaffolds, with submicron diameters of $0.85 \pm 0.43$ and $0.94 \pm 0.51 \mu \mathrm{m}$, respectively. An applied voltage of $30 \mathrm{kV}$ resulted in a decrease in fibre diameter for both scaffolds, down to $0.125 \pm 0.047 \mu \mathrm{m}$ for PCL and $0.108 \pm 0.033 \mu \mathrm{m}$ for RA-loaded PCL electrospun scaffolds (Fig. 1A-C and Table S1, ESI $\dagger$ ). The amounts of RA loaded onto the scaffolds were calculated to be $7.54,1.51$ and $0.30 \mu \mathrm{g}$ for RA $0.25,0.05$ or $0.01 \%$ scaffolds. The release of RA from RA-loaded PCL electrospun scaffolds at different RA concentrations was measured as a preselection step to distinguish which scaffold provided the optimum release concentration. An earlier release plateau was seen for RA-loaded PCL electrospun scaffolds processed at $30 \mathrm{kV}$ compared to scaffolds processed at $15 \mathrm{kV}$, indicating a lower loading capacity. Hence, the release rate profile for RA-loaded PCL electrospun scaffolds processed at $15 \mathrm{kV}$ provided a more controlled sustainable release of RA for up to a week compared to scaffolds electrospun at $30 \mathrm{kV}$, which showed a burst release of more than $50 \%$ at day 1 (Fig. $1 \mathrm{D}$ and E). This optimum processing parameter at an applied voltage of $15 \mathrm{kV}$ was additionally investigated using minoxidil, another hydrophobic drug known to stimulate elastin synthesis. The results showed similar controlled release of minoxidil, confirming the electrospinning method's versatility and potential (Fig. S1, ESI $\dagger$ ).
RA concentration selection process by DNA and elastin analysis

DNA and elastin analyses were conducted to preselect the best RA concentration which induced the highest cell proliferation and elastin synthesis (Fig. 2). Contact and non-contact cell seeding on the RA-loaded PCL electrospun scaffolds were conducted to distinguish the influence of cell-material contact and RA released in the medium, on HDF's growth and elastin production. In both seeding methods, RA $0.25 \%$ scaffolds inhibited cell growth at all time points. At day 1, RA $0.05 \%$ scaffolds showed a significant decrease, but a significant increase at day 4 for contact and non-contact seeding. For RA $0.01 \%$ scaffolds, a significant increase was seen in both seeding methods at days 2 and 4. Elastin quantification was done at day 4, showing a significantly higher production in RA $0.25 \%$ and RA $0.05 \%$ scaffolds than in the control and RA $0.01 \%$ scaffolds. Hence, RA $0.05 \%$ scaffolds were chosen as the most optimal scaffolds for further analysis. Additionally, the RA 0.05\% scaffolds were able to induce proliferation in growth-inhibited HDFs, as shown in Fig. S1 (ESI $\dagger$ ), through both cell-material contact and RA release.

\section{Seeding methods and cell amount analysis}

The selected RA concentration (0.05\%) of the RA-loaded PCL electrospun scaffolds was further analysed by comparing the influence in seeding methods at days 2 and 5. These two time points were chosen to provide sufficient proliferation study and represent the early phase of the FBR. Cell-ESP(RA) displays contact seeding on RA-loaded electrospun scaffolds with cellESP as its direct control. Cell-RA represents the non-contact
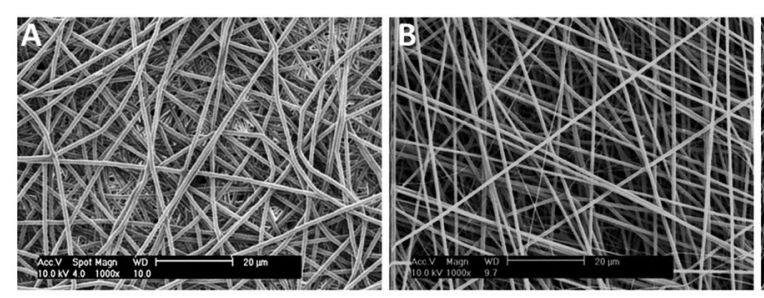

D

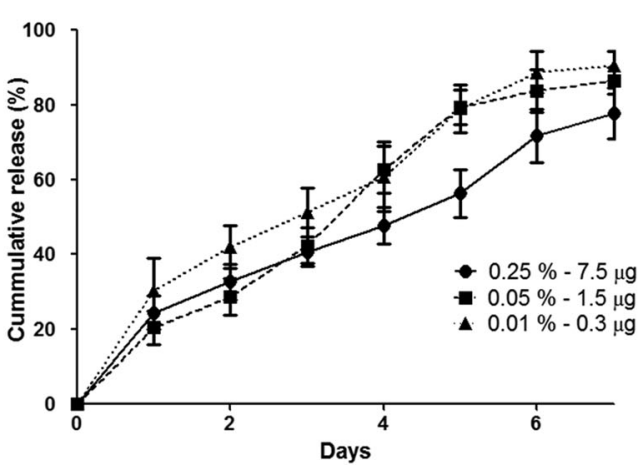

E

Retinoic Acid 30 kV

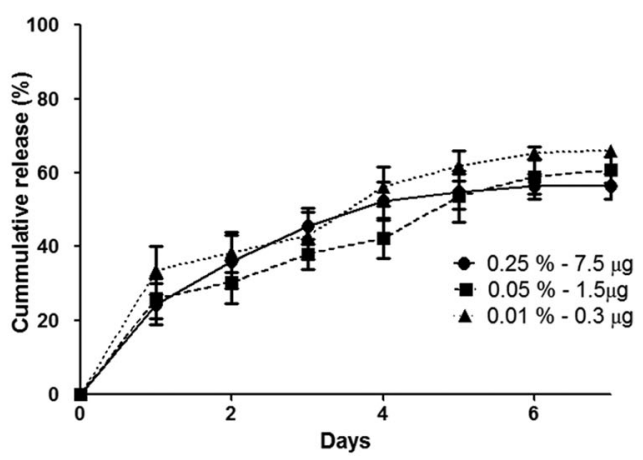

Fig. 1 Electrospun characterization on fibre morphology and RA released. (A-C) SEM images of (A) PCL and (B) RA-loaded PCL electrospun scaffolds processed at $15 \mathrm{kV}$, and RA-loaded PCL electrospun scaffolds processed at $30 \mathrm{kV}$. Scale bar: (A and B) $20 \mu \mathrm{m}$, (C) $5 \mu \mathrm{m}$. (D and E) Release rate profile was measured up to day 7 for RA-loaded PCL electrospun scaffolds at different concentrations (\%) and loading capacity ( $\mu$ g). Scaffolds spun at (D) $15 \mathrm{kV}$ showed a higher cumulative controlled release than those at (E) $30 \mathrm{kV}$. Data are shown as mean $\pm \mathrm{s} . \mathrm{d}$. $(n=3)$. 
A

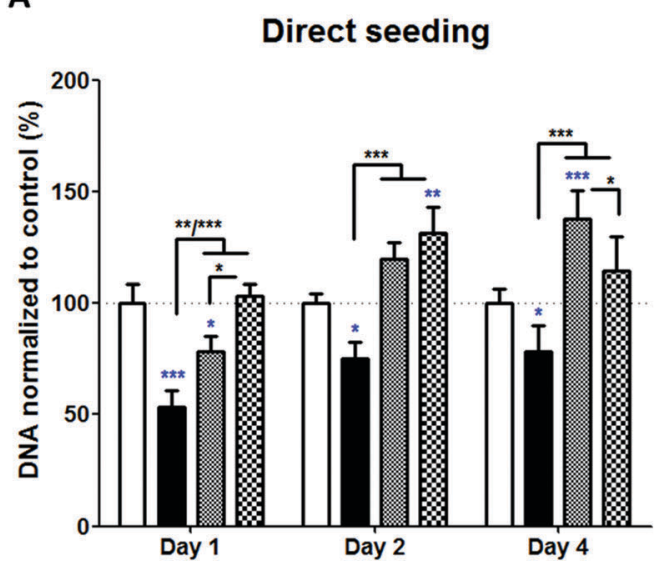

B

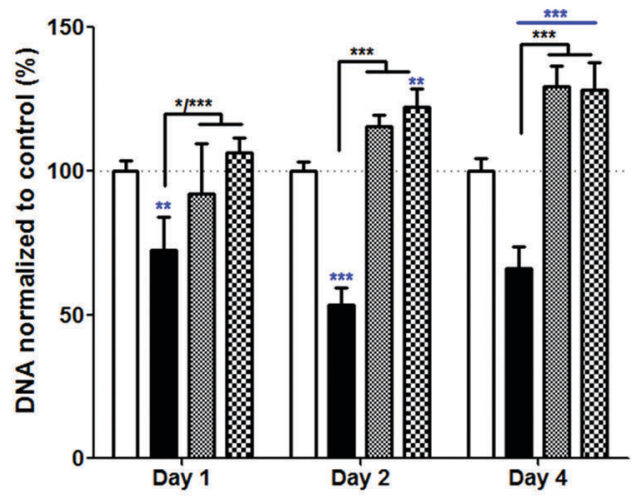

C

Elastin synthesis

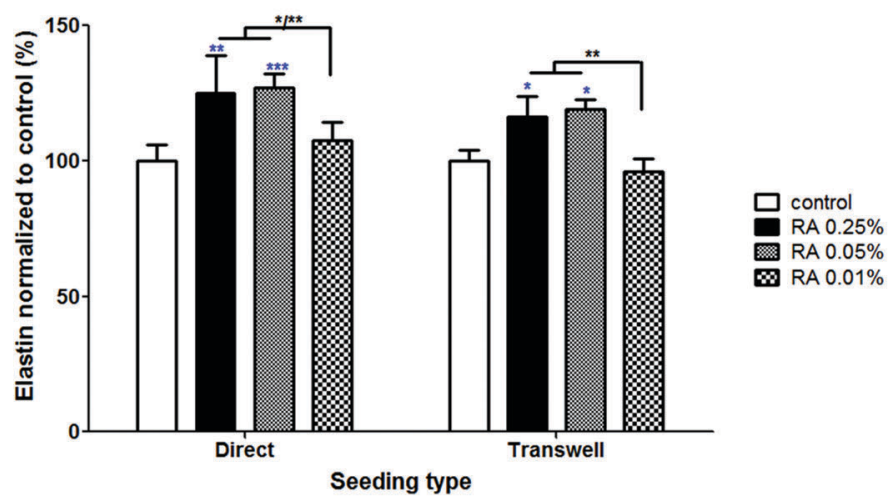

Fig. 2 DNA and elastin analysis. Different electrospun scaffolds are represented by different bar patterns, in which RA-loaded PCL electrospun scaffolds are shown at different concentrations (\%) and loading capacity (mg). Data are normalized in percentage to PCL electrospun scaffolds (control) and shown as mean \pm s.d. $(n=3)$. (A and B) HDFs seeded directly or exposed through a transwell with RA $0.25 \%-5$ mg scaffolds, inhibited cell growth, while other concentrations provided an increase compared to the control. (C) Elastin synthesis measured at day 4 showed a significant increase in elastin production for RA $0.25 \%-5 \mathrm{mg}$ and RA $0.05 \%-1 \mathrm{mg}$. Blue stars $\left({ }^{*} p<0.05,{ }^{* *} p<0.01\right.$, and $\left.{ }^{* * *} p<0.001\right)$ indicate statistical significances in comparison to the control, while black stars evaluate statistical differences between the different RA-loaded PCL electrospun scaffolds.

seeding with cells as its direct control. An additional seeding method, cell-ESP-RA, was added to clearly distinguish the effect of RA release and cell-material contact on hMSC and HDF behaviour (Fig. 3).

Cell amount analysis showed a statistically significant decrease in hMSC amount in RA-loaded PCL electrospun scaffolds at both day 2 and day 5 . HDF cultures showed a more similar trend at day 2, with the exception of cell-ESP(RA) having a higher cell amount than cell-ESP as its direct control. At day 5, however, a comparison of different cultures indicated an increase of cell quantity in the presence of RA-loaded PCL electrospun scaffolds. Nevertheless, for both cell types and time points non-contact seeding showed a higher cell amount than contact seeding. These results indicate the versatility of the RA effect on proliferation of different cell types and cell culture setups.

\section{Cell morphology analysis}

Cell image analysis was conducted to provide insight on cell morphology and attachment on RA electrospun scaffolds.
SEM images showed fewer flat HDFs in RA electrospun scaffolds compared to those in control PCL electrospun scaffolds (Fig. S3, ESI $\dagger$ ). However, immunostaining of scaffolds at day 2 was chosen to appreciate cell-material interactions and the influence of RA on cell morphology and focal adhesion through $\alpha$-actin and vinculin expression. hMSCs seeded on RA scaffolds containing cultures exhibited less stressed actin fibres compared to cultures without RA. While in HDF cultures, more prominent actin fibres were seen in cultures containing RA scaffolds than in cultures without RA, showing differences in the RA effect on different cell types. Additionally, HDFs exposed to RA scaffolds provided a more spread out morphology, while HDFs without RA scaffold exposure were found to be more elongated. Nevertheless, in both hMSC and HDF cultures, vinculin points seen in cell-ESP(RA) cultures were more distinctive compared to those in other cultures (Fig. 4).

\section{ECM analysis of hMSC cultures}

As shown in Fig. 5A, hMSCs seeded on electrospun scaffolds provided a significantly higher elastin synthesis compared to 
A
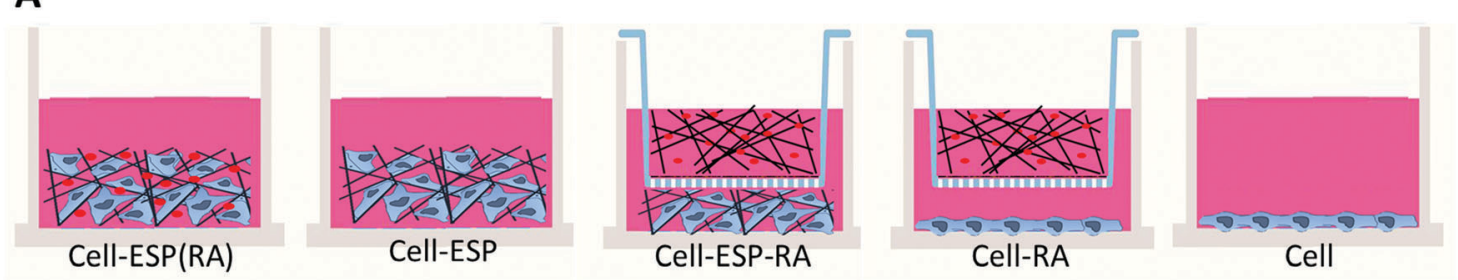

B

hMSC culture

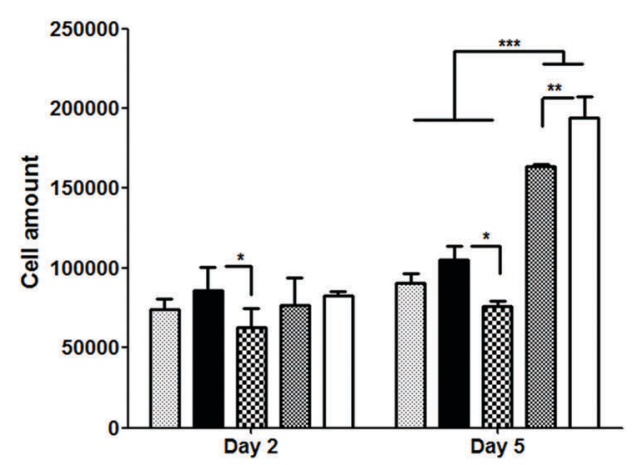

C

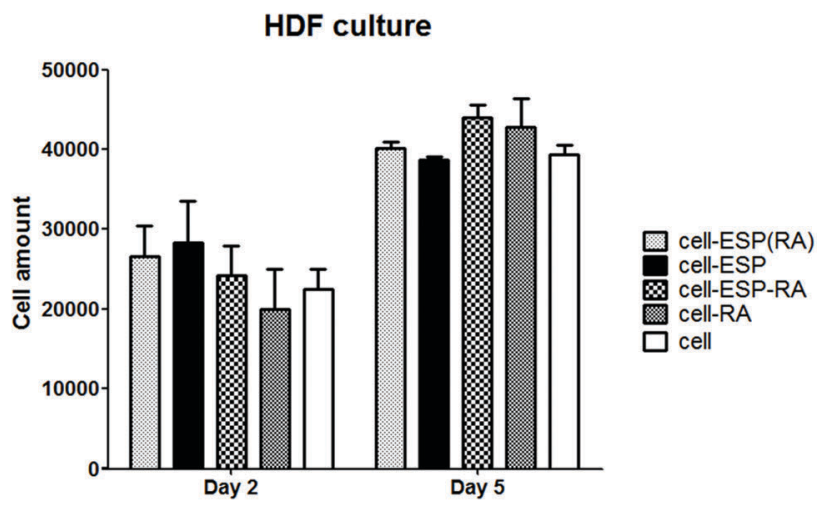

Fig. 3 Seeding methods and the proliferation rate for RA $0.05 \%-1 \mathrm{mg}$ loaded scaffolds. (A) Schematic displaying the different in vitro culture seeding methods used to further analyse and distinguish the effect of contact and non-contact seeding. (B and C) Different seeding setups are represented by different bar patterns and the cell amount is measured at days 2 and 5 . Data are shown as mean \pm s.d. $(n=3)$. (B) A statistically significant difference was seen in contact and non-contact hMSC cultures. (C) HDF proliferation rate showed a significant decrease in cell-RA compared to cell-ESP (RA) and cellESP cultures. Blue stars $\left({ }^{*} p<0.05,{ }^{* *} p<0.01\right.$, and ${ }^{* * *} p<0.001$ ) indicate statistical significances in comparison to the control in this case cell culture, red stars indicate the highest DNA content, and black stars indicate statistical differences between the different cultures.

tissue treated culture plates. A significant increase of elastin was observed in both cell-ESP(RA) and cell-ESP-RA compared to cell-ESP, as well as cells on tissue culture plates (cell control). Total elastin analysis (Fig. S4a, ESI $\dagger$ ) displayed an increase in elastin content in hMSC cultures containing RA-loaded PCL electrospun scaffolds. Cell-ESP(RA) and cell-RA cultures stimulated a significantly higher total elastin content than cell control hMSC cultures.

hMSCs in cell-ESP(RA) and cell-ESP-RA provided a significantly higher collagen synthesis than hMSCs in cell-RA and cell control cultures (Fig. 5B). No significant difference was seen in contact and non-contact cultures, with or without RA-loaded PCL electrospun scaffolds. In total collagen analysis (Fig. S4b, ESI $\dagger$ ), a decrease was measured in cultures with RA-loaded PCL electrospun scaffolds with the exception of cellESP(RA).

The GAG content normalized by DNA (GAG/DNA) was measured to investigate the capability of RA $0.05 \%-1 \mathrm{mg}$ scaffolds to promote hMSC GAG production (Fig. 7). Cell-ESP-RA cultures provided a significant increase in the GAG/DNA content at day 2. At day 5 , the significant increase in cell-ESP-RA was further pronounced, resulting in the highest GAG/DNA levels. Overall, for total GAG levels, non-contact seeding provided a significantly higher GAG content (Fig. S6, ESI $\dagger$ ). These results show the capability of RA-loaded scaffolds to enhance the hMSC production of ECM proteins.

\section{Elastin and collagen analysis of HDF cultures}

For HDFs, cell-ESP(RA) cultures provided the highest significant value of elastin per cell secretion, followed by cell-ESP-RA cultures, while cell-RA cultures were slightly higher than cell cultures (Fig. 6A). Similarly, for total elastin production in HDF cultures, both cell-ESP(RA) and cell-ESP-RA provided the highest significant total elastin content compared to all the other cultures (Fig. S5a, ESI $\dagger$ ).

As shown in Fig. 6B, the cell-ESP control provided a significant increase in collagen per cell production compared to the cell control culture. Cell-ESP-RA cultures showed the highest collagen content per cell secretion, providing a significantly higher collagen production than in cell-RA and cell cultures. Total collagen analysis showed similar results as seen in Fig. S5b (ESI $\dagger$ ). A significantly higher collagen content was found in cell-ESP than those in cell cultures. The highest producing collagen content culture, cell-ESP-RA, stimulated a significantly higher total collagen production than in cell-RA and cell cultures. Similar to hMSCs, the HDF secretion of elastin and collagen was enhanced on RA-loaded scaffolds.

\section{Discussion}

Electrospinning parameters are tuneable to provide optimal versatility to design scaffolds for regenerative medicine applications. ${ }^{6}$ 

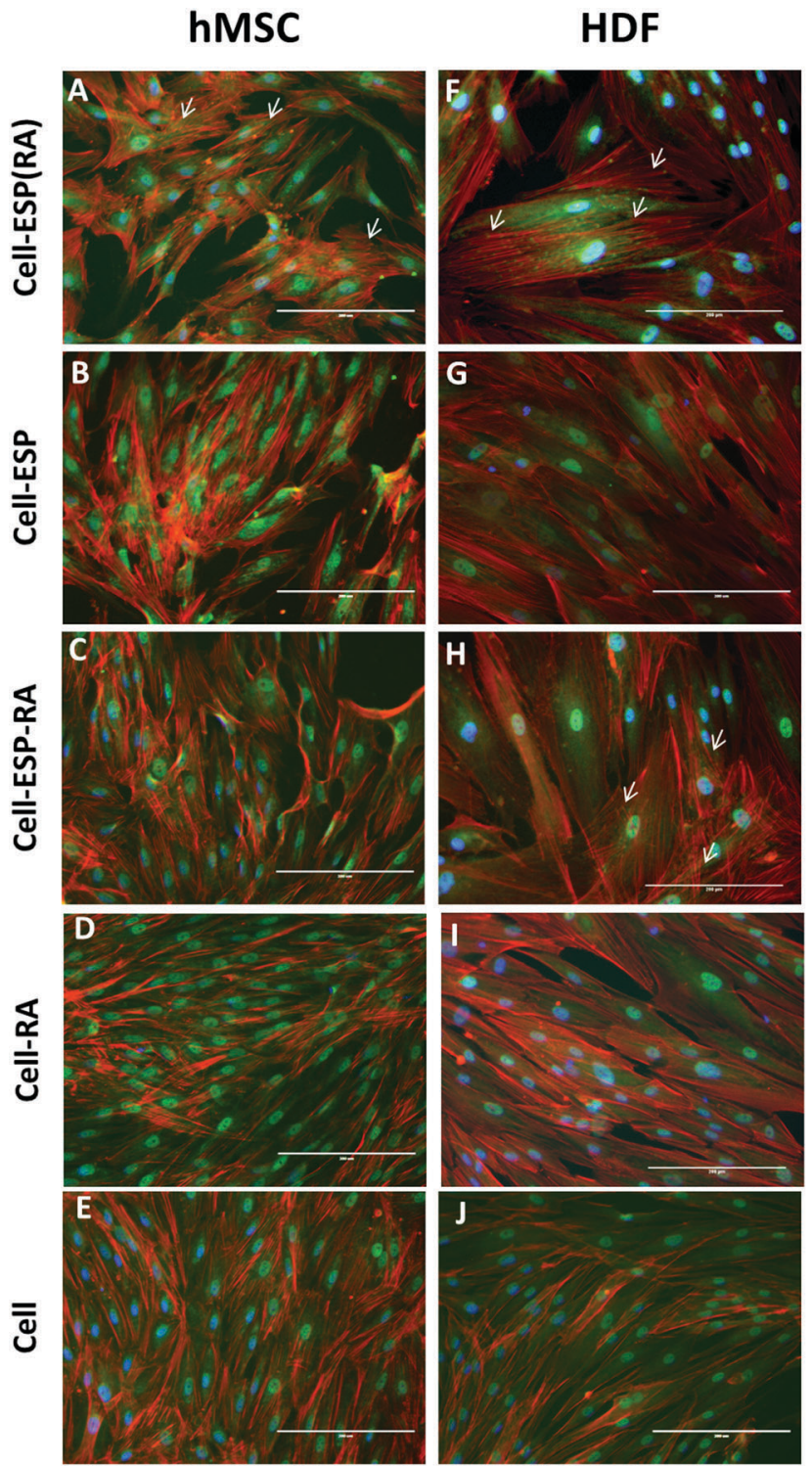

Fig. 4 Immunostaining of cell actin fibres and vinculin expression. Fluorescence images show vinculin (green), phalloidin (red) and DAPI (blue) immuno-stained cells in different culture setups at day 2. Immunostaining images of hMSCS (A-E) showed pronounced stress actin fibres in cell-ESP and cell compared to cell-ESP(RA), cell-ESP-RA, and cell-RA. In HDF cultures $(F-J)$, cells were more spread out in cell-ESP(RA), cell-ESPRA, and cell-RA compared to cell-ESP and cell. Vinculin expression (white arrows) was distinctly seen in cell-ESP(RA) for hMSC cultures, and in cellESP(RA) and cell-ESP-RA in HDF cultures. Scale bar: $200 \mu \mathrm{m}$.

Optimized parameters and applied voltage variation resulted in an adaptable fibre diameter from submicron to nanoscale size, while still maintaining a similar fibre morphology on both RA-loaded PCL and PCL electrospun scaffolds. Applied voltage is a process parameter that can be directly tuned and is considered critical to deliver a steady stream of polymer solution. ${ }^{25}$ It provides the necessary electric field to overcome the surface tension of the polymeric droplet ejected from the electrospinning nozzle, resulting in a continuous charge jet for fibre formation. ${ }^{2}$ Traditionally, an increase in the applied voltage results in a decrease in fibre diameter, ${ }^{26}$ as also seen in our study. However, there have been opposing results, such as a proportional relation on the applied voltage and the fibre diameter. Meechaisue et $a .^{27}$ showed an increase in fibre diameter from 2.5 to $5.8 \mu \mathrm{m}$ by increasing the voltage from 10 to $25 \mathrm{kV}$, which could be due to the increase in the mass flow rate from the electric field increase. However, other studies using different polymer types and viscosity have showed changes in the applied voltage lead to no significant differences in the fibre diameter, ${ }^{28,29}$ indicating that other parameters may modulate the effect of the applied voltage. Nonetheless, all studies conclude that an optimum range of voltage is needed to provide a smooth non-beaded fibre morphology.

Optimum fibre morphology and composition have been necessary for a variety of electrospinning purposes, such as for drug delivery purposes as seen here. The properties of the loaded drug and polymer type not only influence the electrospinning parameter tuning but also loading and release outcome. Various studies have concluded that hydrophobic polymers, such as PCL, poly(glycolic acid) and poly(lactic-coglycolic acid), provide a longer release potential than hydrophilic polymers. ${ }^{30,31}$ Owing to this, the use of hydrophobic drugs, like RA, coupled with a hydrophobic polymer, like PCL, provides an additional advantage with regard to solubility properties in organic solvents, reducing the chances of crystalline formation of RA on the fibre's surface and the consequent burst release. $^{32}$ Nevertheless, as PCL was not soluble in methanol alone, while RA is, a combination of chloroform and methanol as a solvent for RA-loaded PCL electrospun scaffolds may further contribute to the sustained release of RA. ${ }^{33}$ Zhao et al. ${ }^{33}$ observed solvent blends of dichloromethane and methanol to provide a more sustainable release of L-ascorbic acid 2-phosphate magnesium than complex coaxial electrospinning, due to the PCL barrier formed by dichloromethane evaporating before methanol, effortlessly encapsulating the drug. Moreover, larger diameter fibres of submicron size provided a more desirable controlled release with a reduced burst and a higher total cumulative release. This could be caused by the decrease in surface area when releasing RA from larger diameter fibres, as similarly explained by Cui et $a .^{31}$ Taking this into account, a higher surface area of smaller diameter fibres could initiate a burst release upon sterilization before the actual release study was conducted, leading to a lesser cumulative release measured. Hence in our study, we chose to further investigate cell response on electrospun meshes fabricated with $15 \mathrm{kV}$, resulting in a higher fiber diameter, which supported almost the complete release of RA in a week's time.

Various studies have shown the role of RA in controlling proliferation. In certain systems and depending on the cell type, RA can function as either an inhibitor or an enhancer of cell growth. ${ }^{34}$ Kirschner et al. ${ }^{35}$ showed the enhancing function of RA at $1 \mu \mathrm{M}$ concentration in corneal stromal fibroblasts after 24 hours of exposure. In contrast, many studies have shown that exposure to $1 \mu \mathrm{M}$ RA or more inhibits MSC proliferation, ${ }^{36,37}$ supporting the results in our cell quantification. Lotan et al. ${ }^{38}$ studied the cell growth of various untransformed and neoplastic 
A

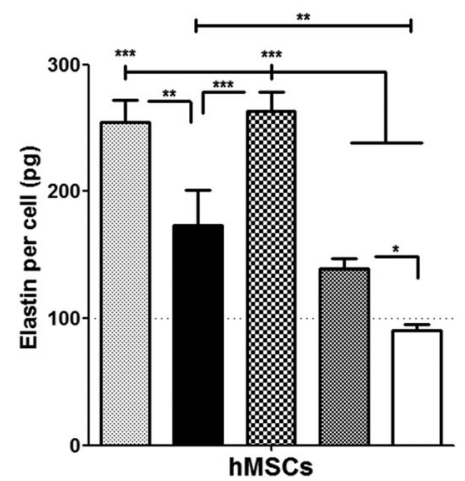

B

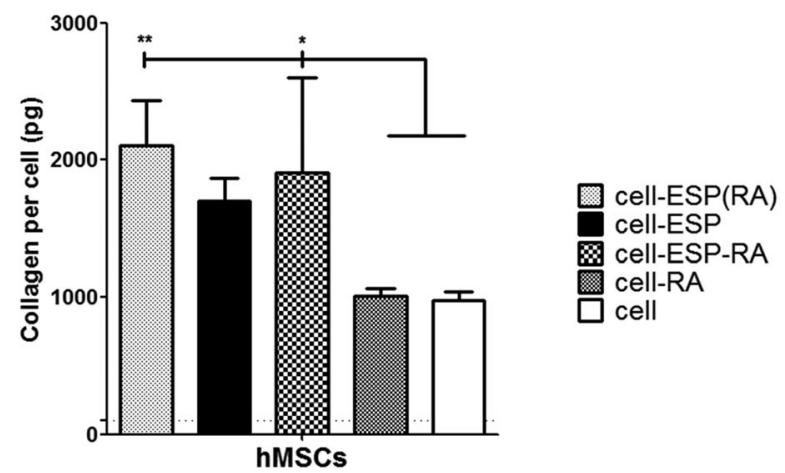

Fig. 5 Elastin and collagen analysis of the hMSC culture at day 5. Different seeding setups are represented by different bar patterns. Data are shown as mean \pm s.d. $(n=3)$. (A) Elastin analysis showed that cell-ESP(RA), cell-ESP and cell-ESP-RA provided an significant increase in elastin per hMSC secretion compared to cell-RA and cell control. Cell-ESP-RA was significantly higher than cell-ESP. (B) Collagen analysis displayed a significant increase in collagen production per hMSC on cell-ESP(RA) and cell-ESP-RA compared to cell-RA and cell control. Black stars $\left({ }^{\star} p<0.05,{ }^{* *} p<0.01\right.$, and $\left.{ }^{* * *} p<0.001\right)$ indicate statistical significances between the different culture setups.

A

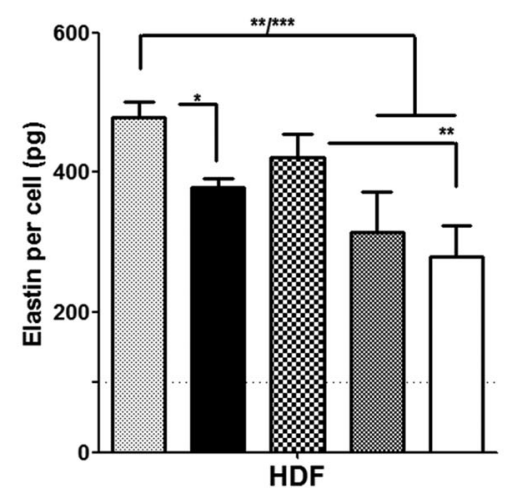

B

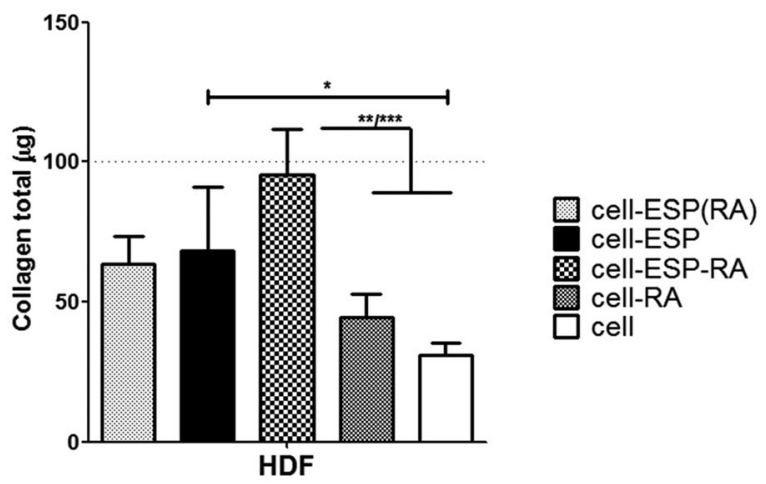

Fig. 6 Elastin and collagen analysis of the HDF culture at day 5. Different seeding setups are represented by different bar patterns. Data are shown as mean \pm s.d. $(n=3)$. (A) Elastin analysis displayed a significantly higher elastin per cell secretion on cell-ESP(RA) and cell-ESP-RA compared to other cultures. (B) Collagen analysis showed that cell-ESP provided a significantly higher collagen per cell secretion compared to cell cultures. Cell-ESP-RA was significantly higher than cell-RA and cell control. Black stars $\left({ }^{*} p<0.05,{ }^{* *} p<0.01\right.$, and $\left.{ }^{* *} p<0.001\right)$ indicate statistical significances between the different culture setups.

cells, and observed a decrease in DNA synthesis of HDF upon exposure to $10 \mu \mathrm{M}$ RA for four days. This concentration, however, was substantially higher than the RA released from the selected RA-loaded PCL electrospun scaffolds (0.05\%), and more similar to $0.25 \%$ RA-loaded PCL electrospun scaffolds. Other RA studies using HDFs ${ }^{39,40}$ support the decrease in cell proliferation with high RA concentration. In non-confluent cultures and proliferating cells, exposure to RA has been known to inhibit proliferation, ${ }^{41,42}$ as also seen in our earlier cell quantification time points. However, as a monolayer of cells gets built and cells tend to proliferate less, RA influences the cell behaviour by inducing proliferation. Cell growth was observed to increase in HDF growth inhibited cells $^{43}$ and the monolayer culture ${ }^{44}$ upon exposure to RA. This induced proliferation by RA is dose-dependent with the decrease in proliferation at a high RA concentration $\left(>2.5 \mu \mathrm{g} \mathrm{ml}{ }^{-1}\right)$.
To support this assumption, additional cell quantification was done using confluent cultures and resulted in an increase in cell proliferation in cultures with RA-loaded PCL electrospun scaffolds.

Absolute and relative quantities of collagen and elastin have a major impact on the biomechanical properties of vessels. ${ }^{45}$ Collagen and elastin are the two main structural components of the vascular ECM, in which collagen provides tensile stiffness and elastin the elastic properties. Furthermore, elastin networks are often found in close association with dense collagenous structures. ${ }^{45}$ Another ECM protein, proteoglycans, consists of core proteins covalently linked to GAGs. They are in charge of vascular compressibility, work together with collagen and elastin for the viscoelastic properties supplying the necessary elasticity to stretch and recoil. ${ }^{46,47}$ These ECM proteins have been 


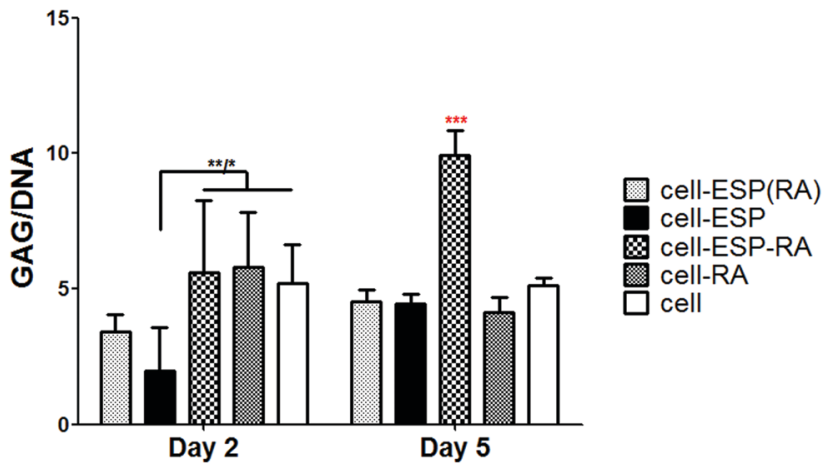

Fig. 7 GAG/DNA analysis of hMSC cultures. Different seeding setups are represented by different bar patterns. Data are shown as mean \pm s.d. $(n=3)$. At day 2, non-contact seeding provided a significantly higher GAG/ DNA content compared to cell-ESP cultures. At day 5, cell-ESP-RA displayed the highest GAG/DNA content compared to all the other cultures. Black stars $\left({ }^{*} p<0.05, * * p<0.01\right.$, and $\left.{ }^{* * *} p<0.001\right)$ indicate statistical significances between the different culture setups, while red stars indicate the highest value.

extensively studied on their earliest and regular expression in human wound healing ${ }^{48}$ and for this reason we have decided day 5 to be a suitable last time point to provide sufficient ECM protein production in vitro. Moreover, the main component of muscular arteries is the media, which is composed of VSMC aligned concentrically along with collagen and elastin fibres and proteoglycans. ${ }^{49}$ These ECM proteins play an essential role in the vessels' bio-functionality of hydration, ion filtration, and growth factor maintenance and cell-matrix interactions. For this reason, regulation of these proteins is crucial for appropriate tissue regeneration. An increase in sulphated proteoglycan and GAG contents in RA-loaded PCL electrospun scaffolds could indicate VSMC differentiation. RA is highly involved in early SMC differentiation, in which treatment with embryonic stem cells promotes their differentiation towards SMCs. ${ }^{50}$ Bone marrowderived MSCs have also been shown to exhibit molecular and functional attributes of SMCs. ${ }^{51}$

The metabolism of RA by the human skin and dermal fibroblasts $^{52,53}$ and its effect on skin elastin ${ }^{54}$ and collagen ${ }^{55}$ production has been well documented clinically and experimentally, specifically in the photodamaged skin. Here, exposure to RA from RA-ESP scaffolds revealed an increase in elastin synthesis in hMSC and HDF cultures. A similar released concentration of about $10 \mu \mathrm{M}$ RA after 24-48 hours showed 2-3 fold elastin synthesis in chick embryonic skin fibroblasts and VSMCs. ${ }^{17}$ Compared to cell proliferation function, induced collagen and elastin synthesis by RA is dose, time and cell type dependent, which leads to different signalling transduction pathway activation. ${ }^{56}$ RA released from RA-ESP scaffolds with no direct contact to HDFs provided a slightly higher collagen secretion than RA-ESP with direct contact. The difference in collagen synthesis could be due to further degradation of RA-ESP scaffolds from direct contact of the cells, causing an increase in RA released above the critical range of RA concentration for collagen induction. ${ }^{57}$ In contrast to collagen production, HDF exposed to RA-loaded PCL electrospun scaffolds increased in elastin synthesis, specifically when in contact with electrospun scaffolds. The difference in RA function observed in cells seeded in contact with RA-loaded PCL electrospun scaffolds could be due to the increase in RA released by increasing RA-loaded PCL electrospun scaffold degradation from direct cell-material contact. $^{58}$

Though providing a slight increase, RA influence in collagen synthesis is less influential than geometry induction. This was similarly seen in the study by Rothan et al. ${ }^{77}$ where collagen I and III were upregulated in skin fibroblasts seeded on 3D scaffolds compared to 2D substrates. Moreover, though our results are limited to the difference in the chemistry of the $3 \mathrm{D}$ PCL electrospun scaffold and the 2D polystyrene cultured plate, Sefcik et al. showed similar collagen I upregulation in human adipose stem cells cultured on 3D electrospun fibres compared to the 2D substrate with similar chemistry. ${ }^{59}$ This can be explained by the 3D architecture of electrospun scaffolds that provides an advantage in ECM protein production, specifically in collagen secretion compared to $2 \mathrm{D}$ tissue cultured plates. ${ }^{60}$ The influence of the 3D architecture seems to provide an enhancement in elastin synthesis as well, though not as significant as collagen secretion. Lin et al. ${ }^{61}$ observed a twofold upregulation in elastin gene expression and induced elastin protein secretion in VMSCs cultured in 3D polyurethane scaffolds compared to $2 \mathrm{D}$ culture studies. Furthermore, the addition of RA in cultures increased the 3D effect significantly, providing elastin enhancement with or without direct contact to RA-ESP scaffolds. Additionally, despite the common decrease of nutrients and oxygen delivery in $3 \mathrm{D}$ constructs, ${ }^{62}$ the increase in both elastin and collagen suggests sufficient nutrient and oxygen delivery.

Enhancement in ECM synthesis upon RA release from RA-loaded PCL electrospun scaffolds suggests an effect on cell morphology as well. Sammons et al. ${ }^{63}$ explained the inhibitory effect of RA on human hematopoietic stem cell proliferation to be mediated by the increase of adhesion molecules released from the marrow after RA treatment. Moreover, RA receptors are associated with gene transcription involved in cell adhesion such as different integrins, laminins and collagen, and hence knocking out RA receptors results in losing capabilities of adherence and migration. ${ }^{64}$ Adhesion molecules are connected to the cell's cytoskeleton, which elucidates cell's morphological observation in cell-ESP(RA) cultures, which exhibited a higher expression of vinculin adhesive proteins. ${ }^{65}$ In addition, both Nakagawa et al., and Platko et al., have shown RA's involvement in cell migration through expression of tyrosine-phosphorylated focal adhesion kinase (FAK) ${ }^{66}$ and paxillin, ${ }^{67}$ in which cells were stimulated to differentiate upon exposure to RA.

Vascular support is critical for the survival and functioning of all living tissues. Vascular access is hence essential for the appropriate recovery of tissue damage. ${ }^{51}$ Our in vivo bioreactor approach to create TEBV by forming a tissue capsule could provide the necessary cell source for differentiation to VSMCs and (myo)fibroblasts, the two main cells in blood vessels. ${ }^{22}$ In addition, to create truly physiological and functional TEBVs, the presence of adequate vascular ECM proteins, collagen, 
elastin, GAG and proteoglycans is essential for the integrity of the vascular tissue. ${ }^{68}$ The addition of RA-loaded PCL electrospun scaffolds could provide a promising platform for support and functionality of potential TEBVs and potentially other tissue engineering applications.

RA is a metabolite crucial for the early embryonic development and involved in various stem cell lineage differentiations. ${ }^{69-71}$ Monteiro et al. showed that RA induced adipogenic differentiation of embryonic stem cells. ${ }^{72}$ Recently, Zhang et al. used RA to potentiate Wnt3A-induced osteogenic differentiation of MSCs. ${ }^{73}$ Neurogenesis has also been modulated through RA direct exposure in a medium and through a biomaterial. A higher concentration of RA can induce neuronal differentiation in a controlled developmental manner. ${ }^{74}$ By seeding induced RA-mouse embryonic stem cells, Xie et al., showed that the PCL electrospun scaffolds enhanced neurogenesis and guided neurite outgrowth. Hence, the combination of electrospun scaffolds and retinoic acid has been mentioned to potentially provide a better strategy for nerve injury repair. ${ }^{75}$ Previous studies have tried to incorporate retinoic acid directly upon electrospinning or through encapsulation but are yet to achieve a more controlled release in a simplified manner. ${ }^{76}$ Using this method, retinoic acid, minoxidil and potentially other compounds can be incorporated and controlled released effectively for target tissue regeneration and other biomedical applications.

\section{Conclusion}

In this study, we evaluated the fibre morphology and the RA release profile of RA-loaded PCL electrospun scaffolds and their influence on hMSC and HDF behaviour. Depending on the targeted cell type and RA concentration loading, the RA-loaded PCL electrospun scaffolds were able to stimulate or inhibit cell proliferation, adhesion, morphology and ECM secretion. The versatility of the developed technique and the strong association of RA in regulating cell fate provide a promising platform for cell therapy and tissue engineering.

\section{Conflicts of interest}

There are no conflicts to declare.

\section{Acknowledgements}

This research forms part of the Project P3.03 DialysisXS of the research program of the BioMedical Materials Institute, co-funded by the Dutch Ministry of Economic Affairs, Agriculture and Innovation. The financial contribution by the Nierstichting Nederland is gratefully acknowledged.

\section{References}

1 V. Pillay, C. Dott, Y. E. Choonara, C. Tyagi, L. Tomar, P. Kumar, L. C. du Toit and V. M. K. Ndesendo, A Review of the Effect of Processing Variables on the Fabrication of
Electrospun Nanofibers for Drug Delivery Applications, J. Nanomater., 2013, 2013, 1-22.

2 J. Doshi and D. H. Reneker, Electrospinning process and applications of electrospun fibers, Industry Applications Society Annual Meeting, 1993, Conference Record of the 1993 IEEE, IEEE, 1993, pp. 1698-1703.

3 M. Zamani, M. P. Prabhakaran and S. Ramakrishna, Advances in drug delivery via electrospun and electrosprayed nanomaterials, Int. J. Nanomed., 2013, 8, 2997-3017.

4 J. S. Lee, K. H. Choi, H. D. Ghim, S. S. Kim, D. H. Chun, H. Y. Kim and W. S. Lyoo, Role of molecular weight of atactic poly(vinyl alcohol) (PVA) in the structure and properties of PVA nanofabric prepared by electrospinning, J. Appl. Polym. Sci., 2004, 93(4), 1638-1646.

5 C. J. Buchko, L. C. Chen, Y. Shen and D. C. Martin, Processing and microstructural characterization of porous biocompatible protein polymer thin films, Polymer, 1999, 40(26), 7397-7407.

6 S. Ramakrishna, An Introduction to Electrospinning and Nanofibers, World Scientific, 2005.

7 P. Lu and B. Ding, Applications of Electrospun Fibers, Recent Pat. Nanotechnol., 2008, 2(3), 169-182.

8 C. Xu, R. Inai, M. Kotaki and S. Ramakrishna, Electrospun nanofiber fabrication as synthetic extracellular matrix and its potential for vascular tissue engineering, Tissue Eng., 2004, 10(7-8), 1160-1168.

9 M. M. Stevens and J. H. George, Exploring and engineering the cell surface interface, Science, 2005, 310(5751), 1135-1138.

10 B. L. Banik and J. L. Brown, Polymeric Biomaterials in Nanomedicine A2, in Natural and Synthetic Biomedical Polymers, ed. S. G. Kumbar, C. T. Laurencin and M. Deng, Elsevier, Oxford, 2014, ch. 23, pp. 387-395.

11 M. A. Woodruff and D. W. Hutmacher, The return of a forgotten polymer-Polycaprolactone in the 21st century, Prog. Polym. Sci., 2010, 35(10), 1217-1256.

12 T. J. Sill and H. A. von Recum, Electrospinning: applications in drug delivery and tissue engineering, Biomaterials, 2008, 29(13), 1989-2006.

13 K. K. Jain, Drug Delivery Systems, Humana Press, 2008.

$14 \mathrm{M}$. Rhinn and P. Dolle, Retinoic acid signalling during development, Development, 2012, 139(5), 843-858.

15 J. Varani, R. S. Mitra, D. Gibbs, S. H. Phan, V. M. Dixit, R. Mitra, T. Wang, K. J. Siebert, B. J. Nickoloff and J. J. Voorhees, All-Trans Retinoic Acid Stimulates Growth and Extracellular Matrix Production in Growth-Inhibited Cultured Human Skin Fibroblasts, J. Invest. Dermatol., 1990, 94(5), 717-723.

16 B. Liu, C. S. Harvey and S. E. McGowan, Retinoic acid increases elastin in neonatal rat lung fibroblast cultures, Am. J. Physiol., 1993, 265(5), L430-L437.

17 S. Tajima, A. Hayashi and T. Suzuki, Elastin expression is up-regulated by retinoic acid but not by retinol in chick embryonic skin fibroblasts, J. Dermatol. Sci., 1997, 15(3), 166-172.

18 A. Hayashi, T. Suzuki and S. Tajima, Modulations of Elastin Expression and Cell Proliferation by Retinoids in Cultured 
Vascular Smooth Muscle Cells, J. Biochem., 1995, 117(1), 132-136.

19 S. L. Dahl, A. P. Kypson, J. H. Lawson, J. L. Blum, J. T. Strader, Y. Li, R. J. Manson, W. E. Tente, L. DiBernardo, M. T. Hensley, R. Carter, T. P. Williams, H. L. Prichard, M. S. Dey, K. G. Begelman and L. E. Niklason, Readily available tissueengineered vascular grafts, Sci. Transl. Med., 2011, 3(68), 68ra9.

20 W. Wystrychowski, T. N. McAllister, K. Zagalski, N. Dusserre, L. Cierpka and N. L'Heureux, First human use of an allogeneic tissue-engineered vascular graft for hemodialysis access, J. Vasc. Surg., 2014, 60(5), 1353-1357.

21 W. Mrowczynski, D. Mugnai, S. de Valence, J. C. Tille, E. Khabiri, M. Cikirikcioglu, M. Moller and B. H. Walpoth, Porcine carotid artery replacement with biodegradable electrospun poly-e-caprolactone vascular prosthesis, J. Vasc. Surg., 2014, 59(1), 210-219.

22 F. F. Damanik, T. C. Rothuizen, C. van Blitterswijk, J. I. Rotmans and L. Moroni, Towards an in vitro model mimicking the foreign body response: tailoring the surface properties of biomaterials to modulate extracellular matrix, Sci. Rep., 2014, 4, 6325.

23 A. Ben Driss, J. Benessiano, P. Poitevin, B. I. Levy and J. B. Michel, Arterial expansive remodeling induced by high flow rates, Am. J. Physiol.: Heart Circ. Physiol., 1997, 272(2), H851-H858.

24 J. D. DeBruijn, I. Van Den Brink, S. Mendes, R. Dekker, Y. P. Bovell and C. A. Van Blitterswijk, Bone Induction by Implants Coated with Cultured Osteogenic Bone Marrow Cells, Adv. Dent. Res., 1999, 13(1), 74-81.

25 M. K. Leach, Z. Q. Feng, S. J. Tuck and J. M. Corey, Electrospinning fundamentals: optimizing solution and apparatus parameters, J. Visualized Exp., 2011, 47, DOI: 10.3791/2494.

$26 \mathrm{~V}$. Beachley and X. Wen, Effect of electrospinning parameters on the nanofiber diameter and length, Mater. Sci. Eng., C, 2009, 29(3), 663-668.

27 C. Meechaisue, R. Dubin, P. Supaphol, V. P. Hoven and J. Kohn, Electrospun mat of tyrosine-derived polycarbonate fibers for potential use as tissue scaffolding material, J. Biomater. Sci., Polym. Ed., 2006, 17(9), 1039-1056.

28 C. Zhang, X. Yuan, L. Wu, Y. Han and J. Sheng, Study on morphology of electrospun poly(vinyl alcohol) mats, Eur. Polym. J., 2005, 41(3), 423-432.

29 X. Yuan, Y. Zhang, C. Dong and J. Sheng, Morphology of ultrafine polysulfone fibers prepared by electrospinning, Polym. Int., 2004, 53(11), 1704-1710.

30 S. F. Chou, D. Carson and K. A. Woodrow, Current strategies for sustaining drug release from electrospun nanofibers, J. Controlled Release, 2015, 220(Pt B), 584-591.

31 W. Cui, X. Li, X. Zhu, G. Yu, S. Zhou and J. Weng, Investigation of drug release and matrix degradation of electrospun poly(DL-lactide) fibers with paracetanol inoculation, Biomacromolecules, 2006, 7(5), 1623-1629.

32 S. Zupancic, S. Sinha-Ray, S. Sinha-Ray, J. Kristl and A. L. Yarin, Long-Term Sustained Ciprofloxacin Release from PMMA and Hydrophilic Polymer Blended Nanofibers, Mol. Pharmaceutics, 2016, 13(1), 295-305.
33 X. Zhao, Y. Lui, P. Toh and S. Loo, Sustained Release of Hydrophilic L-ascorbic acid 2-phosphate Magnesium from Electrospun Polycaprolactone Scaffold-A Study across Blend, Coaxial, and Emulsion Electrospinning Techniques, Materials, 2014, 7(11), 7398-7408.

34 M. B. Sporn, The retinoids, Academic Press, 2012.

35 S. E. Kirschner, A. Ciaccia and J. L. Ubels, The Effect of Retinoic Acid on Thymidine Incorporation and Morphology of Corneal Stromal Fibroblasts, Curr. Eye Res., 2009, 9(11), 1121-1125.

36 Z. Y. Su, Y. Li, X. L. Zhao and M. Zhang, All-trans retinoic acid promotes smooth muscle cell differentiation of rabbit bone marrow-derived mesenchymal stem cells, J. Zhejiang Univ., Sci., B, 2010, 11(7), 489-496.

37 A. Oliva, A. Borriello, S. Zeppetelli, A. Di Feo, P. Cortellazzi, V. Ventriglia, M. Criscuolo, V. Zappia and F. Della Ragione, Retinoic acid inhibits the growth of bone marrow mesenchymal stem cells and induces p27Kip1 and p16INK4A up-regulation, Mol. Cell. Biochem., 2003, 247(1), 55-60.

38 R. Lotan, T. Stolarsky, D. Lotan and A. Ben-Ze'ev, Retinoic acid restores shape-dependent growth control in neoplastic cells cultured on poly(2-hydroxyethyl methacrylate)-coated substrate, Int. J. Cancer, 1984, 33(1), 115-121.

39 T. J. Daly and W. L. Weston, Retinoid effects on fibroblast proliferation and collagen synthesis in vitro and on fibrotic disease in vivo, J. Am. Acad. Dermatol., 1986, 15(4), 900-902.

40 R. Hein, H. Mensing, P. K. Muller, O. Braun-Falco and T. Krieg, Effect of vitamin A and its derivatives on collagen production and chemotactic response of fibroblasts, $\mathrm{Br}$. J. Dermatol., 1984, 111(1), 37-44.

41 A. Lacroix, G. Anderson and M. Lippman, Retinoids and cultured human fibroblasts Effects on cell growth and presence of cellular retinoic acid-binding protein, Exp. Cell Res., 1980, 130(2), 339-344.

42 D. L. Nelson and G. Balian, The Effect of Retinoic Acid on Collagen Synthesis by Human Dermal Fibroblasts, Collagen Relat. Res., 1984, 4(2), 119-128.

43 J. Varani, R. S. Mitra, D. Gibbs, S. H. Phan, V. M. Dixit, R. Mitra, Jr., T. Wang, K. J. Siebert, B. J. Nickoloff and J. J. Voorhees, All-trans retinoic acid stimulates growth and extracellular matrix production in growth-inhibited cultured human skin fibroblasts, J. Invest. Dermatol., 1990, 94(5), 717-723.

44 J. K. Jutley, E. J. Wood and W. J. Cunliffe, Influence of Retinoic Acid and TGF- $\beta$ on Dermal Fibroblast Proliferation and Collagen Production in Monolayer Cultures and Dermal Equivalents, Matrix, 1993, 13(3), 235-241.

45 E. M. Green, J. C. Mansfield, J. S. Bell and C. P. Winlove, The structure and micromechanics of elastic tissue, Interface Focus, 2014, 4(2), DOI: 1098/rsfs/2013.0058.

46 J. Y. Xu and G. P. Shi, Vascular wall extracellular matrix proteins and vascular diseases, Biochim. Biophys. Acta, Mol. Basis Dis., 2014, 1842(11), 2106-2119.

47 J. P. Stegemann, S. N. Kaszuba and S. L. Rowe, Review: Advances in vascular tissue engineering using protein-based Biomaterials, Tissue Eng., 2007, 13(11), 2601-2613. 
48 L. E. Tracy, R. A. Minasian and E. J. Caterson, Extracellular Matrix and Dermal Fibroblast Function in the Healing Wound, Adv. Wound Care, 2016, 5(3), 119-136.

49 G. Bou-Gharios, M. Ponticos, V. Rajkumar and D. Abraham, Extra-cellular matrix in vascular networks, Cell Proliferation, 2004, 37(3), 207-220.

50 M. Drab, H. Haller, R. Bychkov, B. Erdmann, C. Lindschau, H. Haase, I. Morano, F. C. Luft and A. M. Wobus, From totipotent embryonic stem cells to spontaneously contracting smooth muscle cells: a retinoic acid and db-cAMP in vitro differentiation model, FASEB J., 1997, 11(11), 905-915.

51 K. Tamama, C. K. Sen and A. Wells, Differentiation of Bone Marrow Mesenchymal Stem Cells into the Smooth Muscle Lineage by Blocking ERK/MAPK Signaling Pathway, Stem Cells Dev., 2008, 17(5), 897-908.

52 R. K. Randolph and M. Simon, Dermal fibroblasts actively metabolize retinoic acid but not retinol, J. Invest. Dermatol., 1998, 111(3), 478-484.

53 J. Bailly, M. Crettaz, M. H. Schifflers and J. P. Marty, In vitro metabolism by human skin and fibroblasts of retinol, retinal and retinoic acid, Exp. Dermatol., 1998, 7(1), 27-34.

54 Z. Chen, M. H. Shin, Y. J. Moon, S. R. Lee, Y. K. Kim, J. E. Seo, J. E. Kim, K. H. Kim and J. H. Chung, Modulation of elastin exon 26A mRNA and protein expression in human skin in vivo, Exp. Dermatol., 2009, 18(4), 378-386.

55 S. Cho, L. Lowe, T. A. Hamilton, G. J. Fisher, J. J. Voorhees and S. Kang, Long-term treatment of photoaged human skin with topical retinoic acid improves epidermal cell atypia and thickens the collagen band in papillary dermis, J. Am. Acad. Dermatol., 2005, 53(5), 769-774.

56 T. B. Zhou, G. P. C. Drummen and Y. H. Qin, The Controversial Role of Retinoic Acid in Fibrotic Diseases: Analysis of Involved Signaling Pathways, Int. J. Mol. Sci., 2013, 14(1), 226-243.

57 J. Varani, R. S. Mitra, D. Gibbs, S. H. Phan, V. M. Dixit, R. Mitra, T. Wang, K. J. Siebert, B. J. Nickoloff and J. J. Voorhees, All-Trans Retinoic Acid Stimulates Growth and Extracellular-Matrix Production in Growth-Inhibited Cultured Human Skin Fibroblasts, J. Invest. Dermatol., 1990, 94(5), 717-723.

58 J. Pena, T. Corrales, I. Izquierdo-Barba, M. C. Serrano, M. T. Portoles, R. Pagani and M. Vallet-Regi, Alkalinetreated poly(epsilon-caprolactone) films: Degradation in the presence or absence of fibroblasts, J. Biomed. Mater. Res., Part A, 2006, 76a(4), 788-797.

59 L. S. Sefcik, R. A. Neal, S. N. Kaszuba, A. M. Parker, A. J. Katz, R. C. Ogle and E. A. Botchwey, Collagen nanofibres are a biomimetic substrate for the serum-free osteogenic differentiation of human adipose stem cells, J. Tissue Eng. Regener. Med., 2008, 2(4), 210-220.

60 S. Rhee, Fibroblasts in three dimensional matrices: cell migration and matrix remodeling, Exp. Mol. Med., 2009, 41(12), 858-865.
61 S. Lin, M. Sandig and K. Mequanint, Three-dimensional topography of synthetic scaffolds induces elastin synthesis by human coronary artery smooth muscle cells, Tissue Eng., Part A, 2011, 17(11-12), 1561-1571.

62 M. J. Barron, C. J. Tsai and S. W. Donahue, Mechanical stimulation mediates gene expression in MC3T3 osteoblastic cells differently in 2D and 3D environments, J. Biomech. Eng., 2010, 132(4), 041005.

63 J. Sammons, N. Ahmed, M. A. Khokher and H. T. Hassan, Mechanisms mediating the inhibitory effect of all-trans retinoic acid on primitive hematopoietic stem cells in human long-term bone marrow culture, Stem Cells, 2000, 18(3), 214-219.

64 Z. Al Tanoury, A. Piskunov, D. Andriamoratsiresy, S. Gaouar, R. Lutzing, T. Ye, B. Jost, C. Keime and C. Rochette-Egly, Genes involved in cell adhesion and signaling: a new repertoire of retinoic acid receptor target genes in mouse embryonic fibroblasts, J. Cell Sci., 2014, 127(Pt 3), 521-533.

65 C. K. Miranti and J. S. Brugge, Sensing the environment: a historical perspective on integrin signal transduction, Nat. Cell Biol., 2002, 4(4), E83-E90.

66 K. Nakagawa, S. Sogo, K. Hioki, R. Tokunaga and S. Taketani, Acquisition of cell adhesion and induction of focal adhesion kinase of human colon cancer Colo 201 cells by retinoic acid-induced differentiation, Differentiation, 1998, 62(5), 249-257.

67 J. D. Platko and A. Yen, Paxillin increases as retinoic acid or vitamin D3 induce HL-60 cell differentiation, In Vitro Cell. Dev. Biol.: Anim., 1997, 33(2), 84-87.

68 M. P. Jacob, C. Badier-Commander, V. Fontaine, Y. Benazzoug, L. Feldman and J. B. Michel, Extracellular matrix remodeling in the vascular wall, Pathol. Biol., 2001, 49(4), 326-332.

69 R. E. Ronn, C. Guibentif, R. Moraghebi, P. Chaves, S. Saxena, B. Garcia and N. B. Woods, Retinoic Acid Regulates Hematopoietic Development from Human Pluripotent Stem Cells, Stem, Cell Rep., 2015, 4(2), 269-281.

70 Y. Jeong and D. J. Mangelsdorf, Nuclear receptor regulation of stemness and stem cell differentiation, Exp. Mol. Med., 2009, 41(8), 525-537.

71 L. J. Gudas and J. A. Wagner, Retinoids Regulate Stem Cell Differentiation, J. Cell. Physiol., 2011, 226(2), 322-330.

72 M. C. Monteiro, B. Wdziekonski, P. Villageois, C. Vernochet, C. Iehle, N. Billon and C. Dani, Commitment of Mouse Embryonic Stem Cells to the Adipocyte Lineage Requires Retinoic Acid Receptor beta and Active GSK3, Stem Cells Dev., 2009, 18(3), 457-463.

73 S. Zhang, X. T. Chen, Y. Hu, J. Wu, Q. Cao, S. Y. Chen and Y. H. Gao, All-trans retinoic acid modulates Wnt3A-induced osteogenic differentiation of mesenchymal stem cells via activating the PI3K/AKT/GSK3 beta signalling pathway, Mol. Cell. Endocrinol., 2016, 422(C), 243-253.

74 K. M. Guan, H. Chang, A. Rolletschek and A. M. Wobus, Embryonic stem cell-derived neurogenesis - Retinoic acid induction and lineage selection of neuronal cells, Cell Tissue Res., 2001, 305(2), 171-176. 
75 J. W. Xie, S. M. Willerth, X. R. Li, M. R. Macewan, A. Rader, S. E. Sakiyama-Elbert and Y. N. Xia, The differentiation of embryonic stem cells seeded on electrospun nanofibers into neural lineages, Biomaterials, 2009, 30(3), 354-362.

76 W. C. Low, P. O. Rujitanaroj, F. Wang, J. Wang and S. Y. Chew, Nanofiber-mediated release of retinoic acid and brain-derived neurotrophic factor for enhanced neuronal differentiation of neural progenitor cells, Drug Delivery Transl. Res., 2015, 5(2), 89-100.

77 H. A. Rothan, I. Djordjevic, H. Bahrani, M. Paydar, F. Ibrahim, N. A. Rahmanh and R. Yusof, ThreeDimensional Culture Environment Increases the Efficacy of Platelet Rich Plasma Releasate in Prompting Skin Fibroblast Differentiation and Extracellular Matrix Formation, Int. J. Med. Sci., 2014, 11(10), 1029-1038. 